\title{
SYNTHESIS, SPECTRAL CHARACTERIZATION, THERMAL AND BIOLOGICAL STUDIES OF SOME NOVEL SCHIFF BASE METAL(II) COMPLEXES
}

\author{
Y. Satyawana, R. Meena, R. V. Singh and N. Fahmi* \\ Department of Chemistry, University of Rajasthan, Jaipur- 302004 (Rajasthan) India \\ *E-mail: nighat.fahmi@gmail.com
}

\begin{abstract}
Metal complexes of $\mathrm{Co}(\mathrm{II})$ and $\mathrm{Ni}(\mathrm{II})$ with Schiff base derived from 2-(2 fluorophenylmethylene) hydrazinecarboxamide $\left(\mathrm{HL}^{1}\right)$ and 2-(2-fluorophenylmethylene) hydrazinecarbothioamide $\left(\mathrm{HL}^{2}\right)$ were synthesized and characterized by elemental analysis, IR, UV-Visible and ${ }^{1}$ HNMR spectroscopy. On the basis of these studies, a hexa-coordinated octahedral geometry of $\mathrm{Co}(\mathrm{II})$ and $\mathrm{Ni}$ (II) complexes has been proposed. The thermal behavior (TGA) of $\mathrm{Co}(\mathrm{II})$ and $\mathrm{Ni}$ (II) complexes were studied to determine thermal stability. The ligand moieties and their complexes were collectively tested for their antimicrobial activity to assess their growth-inhibiting potential against bacteria and fungi. The ligands and their metal complexes were conjointly tested for antimycobacterial activity against Mycobacterium tuberculosis bacterial strain - $\mathrm{H} 37 \mathrm{RV}$ - sensitive to isoniazid and rifampicin drugs. Thiosemicarbazone based $\left[\mathrm{Co}\left(\mathrm{L}^{2}\right)_{2} 2 \mathrm{H}_{2} \mathrm{O}\right]$ was found to inhibit the expansion of Mycobacterium tuberculosisstrain (H37RV).
\end{abstract}

Keywords: Schiff Base Metals Complexes, Spectroscopic Investigation, TGA, Antimicrobial, Antimycobacterial Activity.

@ RASĀYAN. All rights reserved

\section{INTRODUCTION}

The role of metals in biological systems has been well-known over the centuries. Introducing metal ions into a biological system for therapeutic functions and rising medication action. Schiff bases have wide applications in many biological aspects as an awfully vital class of organic compounds. Recently, the chemistry of Schiff base coordination compounds has shown fast development in various fields due to its promising use in biological applications. Metal-containing antibacterial compounds seem to be promising candidates because of their distinctive therapeutic methodology for brand new antibiotic drugs to controlthe growth of bacterial strains. Transition metal complexes with potential biological activity are the most focus of present analysis. Schiff base ligands derived from semicarbazide hydrochloride and thiosemicarbazide became principally appealing because of their broad profile of pharmacological activity that encompasses various kinds of compounds with utterly different activities. It's reported in the Literature $^{2-8}$ that many Schiff bases show biological activities like higher nematicidal ${ }^{9}$, insecticidal ${ }^{10}$, antibacterial $^{11-13}$, antifungal ${ }^{14,15}$, antileukaemia ${ }^{16}$, anti-inflammatory ${ }^{17}$ anti-HIV activity $^{18}$ and antimycobacterial activity among others. Multidrug resistance tuberculosis ${ }^{19}$ (TB), caused by Mycobacterium tuberculosis resistant to at least isoniazid (INH) and rifampicin, is an increasing health problem and a big challenge to TB management programs. There's an excellent need for brand new mycobacterial diagnostic tests to be used in low-income countries. Interest in cobalt and nickel complexes in disease management program continues to be rapidly growing attributable to the makes an attempt to search out complexes with superior potency and fewer toxicity than the prevailing clinical drugs. ${ }^{20}$ Transition metal complexes with azomethine ligands have outstanding potential for inhibiting the expansion of various infective microorganisms and are exploited in pharmacological applications. ${ }^{21-22}$ The present paper deals with the synthesis and characterization of Schiff bases, 2-(2 fluorophenylmethylene) hydrazinecarboxamide $\left(\mathrm{HL}^{1}\right)$ and 2-(2-fluorophenylmethylene) hydrazinecarbothioamide $\left(\mathrm{HL}^{2}\right)$ and their

Rasayan J. Chem., 12(4), 2328-2337(2019)

http://dx.doi.org/10.31788/RJC.2019.1245459

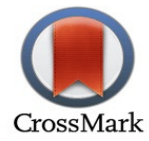


$\mathrm{Co}(\mathrm{II})$ and $\mathrm{Ni}(\mathrm{II})$ complexes along with their qualitative analysis investigations, thermal behavior, antibacterial, antifungal, and antimycobacterial activity. ${ }^{23}$

\section{EXPERIMENTAL}

\section{Methods and Materials}

The $\mathrm{Co}(\mathrm{II})$ and $\mathrm{Ni}$ (II) salts i.e. $\mathrm{Co}(\mathrm{OAc})_{2} \cdot 4 \mathrm{H}_{2} \mathrm{O}$ and $\mathrm{Ni}(\mathrm{OAc})_{2} \cdot 4 \mathrm{H}_{2} \mathrm{O}$, 2-fluorobenzaldehyde, semicarbazide hydrochloride and thiosemicarbazide were purchased from Alfa Aesar and used as such. Standard methods were used to dry and purify the solvents. The molecular weights, chlorine, nitrogenand sulphur were determined by Rast's camphor, Volhard's, Kjeldahl's ${ }^{24}$ and Messenger's ${ }^{25}$ methods respectively. IR spectra of the ligands and their complexes were recorded at Shimadzu FT-IR 8400 by using $\mathrm{KBr}$ pellet technique. ${ }^{1} \mathrm{H}-\mathrm{NMR}$ spectra (DMSO- $d_{6}$ solutions) were recorded at ECS $400 \mathrm{MHz}$ (JEOL) NMR spectrometer (internal standard was TMS). The Varian-Cary/5E spectrophotometer was used to record electronic spectra. Thermogravimetric analysis was recorded from simultaneous thermal analyzer (STA) 6000 (Perkin Elmer).

\section{General Procedure}

\section{Preparation of Ligands}

To prepare ligand $\left(\mathrm{HL}^{1}\right), 2.5 \mathrm{~g}$ of 2-fluorobenzaldehyde and $4.49 \mathrm{~g}$ of semicarbazide hydrochloride was dissolved in ethanol $(100 \mathrm{~mL})$ in the presence of sodium acetate $(1.67 \mathrm{~g}, \mathrm{~mm})$ and to prepare ligand $\left(\mathrm{HL}^{2}\right)$ $2.5 \mathrm{~g}$ of 2-fluorobanzaldehyde and $3.67 \mathrm{~g}$ of thiosemicarbazide was dissolved in ethanol in the molar ratio 1: 1 . The mixtures were refluxed for 5-6 h. After that, the solid product so obtained was filtered off, washed and recrystallized with ethanol and dried under vacuum. (Fig.-1 and 2).<smiles>NC(=O)N/N=C/c1ccccc1F</smiles>

(a)<smiles>NC(=S)N/N=C/c1ccccc1F</smiles>

(b)

Fig.-1. The chemical Structure of Ligands (a) $\mathrm{HL}^{1}$ and (b) $\mathrm{HL}^{2}$

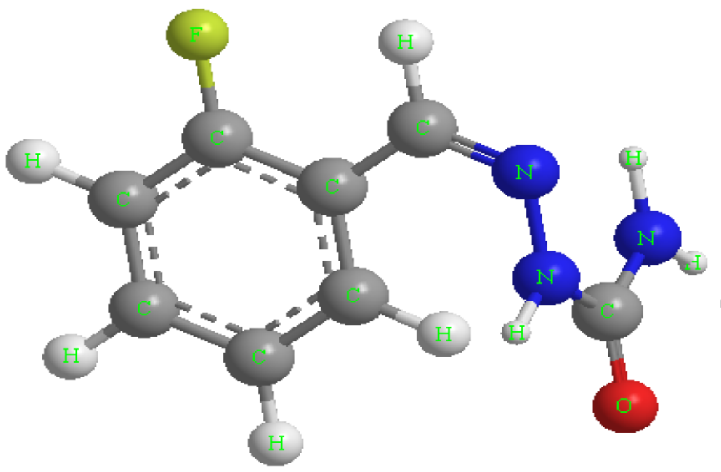

(a)

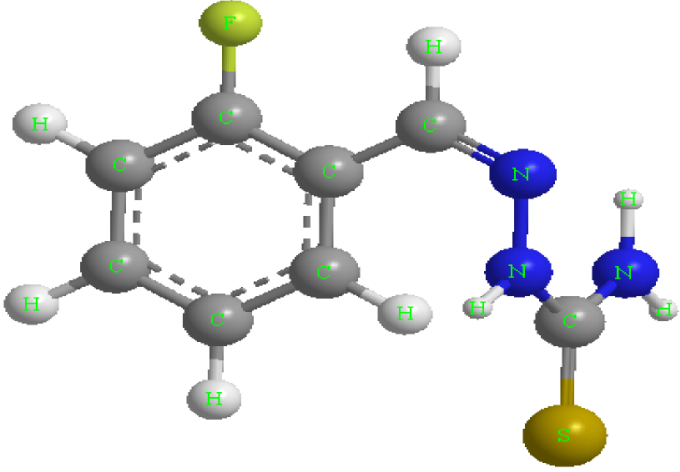

(b)

Fig.-2: The 3D Structure of Ligands (a) $\mathrm{HL}^{1}$ and (b) $\mathrm{HL}^{2}$

Preparation of the Metal Complexes

Metal Complexes of $\mathrm{HL}^{1}$ and $\mathrm{HL}^{2}$ (1: 1)

An aqueous ethanolic solution of $\mathrm{Co}$ (II) acetate $(0.90 \mathrm{~g}, 3.62 \mathrm{mmol})$ and $\mathrm{Ni}$ (II) acetate $(0.90 \mathrm{~g}, 3.62$ mmol) was added to a boiling ethanolic solution of the ligand $H L^{1}$ and $\mathrm{HL}^{2}(0.65 \mathrm{~g}, 3.59 \mathrm{mmol})$ to cause precipitation. The solid products obtained were filtered off and to remove unreacted metal acetates or ligands, these were washed thoroughly with warm water and aqueous ethanol.

Metal Complexes of $\mathrm{HL}^{1}$ and $\mathrm{HL}^{2}(1: 2)$

An aqueous ethanolic solution of $\mathrm{Co}$ (II) acetate $(0.45 \mathrm{~g}, 1.80 \mathrm{mmol})$ and $\mathrm{Ni}$ (II) acetate $(0.45 \mathrm{~g}, 1.80$ mmol) was added to a boiling ethanolic solution of the ligand $H L^{1}$ and $\mathrm{HL}^{2}(0.65 \mathrm{~g}, 3.59 \mathrm{mmol})$ to cause 
RASĀYAN J. Chem.

Vol. 12 | No. 4 | 2328 - 2337| October - December | 2019

immediate precipitation. The solid complexes were filtered off and washed thoroughly with warm water and aqueous ethanol. Thin-layer chromatography using silica gel-G as the stationary phase was used to check the purity. In Table-1 the analytical data for the Schiff base ligands and their metal complexes together with some physical properties are summarized.

Table-1:Analytical Data and Physical Properties of the Ligands and Their Schiff Base Metal Complexes

\begin{tabular}{|c|c|c|c|c|c|c|c|c|c|c|c|c|c|c|c|}
\hline \multirow{3}{*}{ Compound } & \multirow{3}{*}{ Colour } & \multirow{3}{*}{$\operatorname{MP}\left({ }^{\circ} \mathrm{C}\right)$} & \multicolumn{12}{|c|}{ Elemental analysis data } & \multirow{3}{*}{$\begin{array}{l}\text { Moler mass; } \\
\text { found/Calculated }\end{array}$} \\
\hline & & & \multicolumn{6}{|c|}{ Found\% } & \multicolumn{6}{|c|}{ Calculated\% } & \\
\hline & & & $\mathrm{C}$ & $\mathrm{H}$ & $\mathbf{N}$ & $\mathrm{S}$ & $\mathrm{Ni}$ & $\mathrm{C}_{0}$ & $\mathrm{C}$ & $\mathrm{H}$ & $\mathbf{N}$ & $\mathrm{S}$ & $\mathrm{Ni}$ & $\mathrm{Co}_{0}$ & \\
\hline $\mathrm{L}^{1} \mathrm{H}$ & Off white & 218 & 52.87 & 4.19 & 22.01 & - & - & - & 53.04 & 4.45 & 23.19 & - & - & - & $181.06 / 181.17$ \\
\hline $\mathrm{L}^{2} \mathrm{H}$ & White & 192 & 48.51 & 3.89 & 21.03 & 16.01 & - & - & 48.72 & 4.09 & 21.31 & 16.21 & - & - & 197.06/197.23 \\
\hline $\mathrm{Co}\left(\mathrm{L}^{1}\right)(\mathrm{OAc}) \cdot 3 \mathrm{H}_{2} \mathrm{O}$ & violet & 232 & 33.85 & 4.58 & 11.69 & - & - & 16.45 & 34.10 & 4.58 & 11.93 & - & - & 16.73 & $352.09 / 352.18$ \\
\hline $\mathrm{Co}\left(\mathrm{L}^{1}\right)_{2} \cdot 2 \mathrm{H}_{2} \mathrm{O}$ & Pink & 219 & 42.00 & 3.72 & 18.46 & - & - & 12.68 & 42.21 & 3.99 & 18.46 & - & - & 12.94 & $455.16 / 455.28$ \\
\hline $\mathrm{Ni}\left(\mathrm{L}^{1}\right)(\mathrm{OAc}) \cdot 3 \mathrm{H}_{2} \mathrm{O}$ & Light green & 240 & 33.92 & 4.47 & 11.66 & - & 16.53 & - & 34.13 & 4.58 & 11.94 & - & 16.68 & - & $351.62 / 351.94$ \\
\hline $\mathrm{Ni}\left(\mathrm{L}^{1}\right)_{2} \cdot 2 \mathrm{H}_{2} \mathrm{O}$ & Green & 228 & 42.08 & 3.78 & 18.47 & - & 12.61 & - & 42.33 & 3.99 & 18.47 & - & 12.90 & - & $454.73 / 455.07$ \\
\hline $\mathrm{Co}\left(\mathrm{L}^{2}\right)(\mathrm{OAc}) \cdot 3 \mathrm{H}_{2} \mathrm{O}$ & Dark pink & 210 & 32.51 & 4.17 & 11.16 & 8.54 & - & 15.82 & 32.62 & 4.38 & 11.41 & 8.71 & - & 16.00 & $368.04 / 38.24$ \\
\hline $\mathrm{Co}\left(\mathrm{L}^{2}\right)_{2} \cdot 2 \mathrm{H}_{2} \mathrm{O}$ & Dark pink & 203 & 39.15 & 3.48 & 17.00 & 12.95 & - & 11,88 & 39.43 & 3.72 & 17.24 & 13.16 & - & 12.09 & $487.41 / 487.13$ \\
\hline $\mathrm{Ni}\left(\mathrm{L}^{2}\right)(\mathrm{OAc}) \cdot 3 \mathrm{H}_{2} \mathrm{O}$ & Dark Green & 249 & 32.34 & 4.08 & 11.21 & 8.71 & 15.70 & - & 32.64 & 4.38 & 11.42 & 8.71 & 15.95 & - & $367.73 / 368.00$ \\
\hline $\mathrm{Ni}\left(\mathrm{L}^{2}\right)_{2} \cdot 2 \mathrm{H}_{2} \mathrm{O}$ & $\begin{array}{c}\text { Brownish } \\
\text { Green }\end{array}$ & 255 & 39.19 & 3.47 & 17.01 & 12.95 & 11.89 & - & 39.45 & 3.72 & 17.25 & 13.16 & 12.05 & - & $486.53 / 487.17$ \\
\hline
\end{tabular}

\section{Antimicrobial Study}

Test Microorganisms

Medical importance is the criteria of selecting various microbial strains, one Gram(+) bacteria Bacillus subtilis (MTCC 121); one Gram(-) bacteria multi-drug resistant (MDR) strain Escherichia coli (ATCC 35218) and two fungi, Candida albicans (ATCC 200360) and Aspergillus flavus (ATCC 204304).

\section{In-Vitro Antibacterial Activity}

The bactericidal activity of newly synthesized compounds was assessed by the disk/well diffusion susceptibility testing ${ }^{23}$. Test microorganisms were fully grown on a Mueller- Hinton agar medium. Mueller-Hinton agar medium is the sole susceptibility test medium that has been validated by CLSI for screening the antibacterial activity. The agar medium was having a starch $(0.15 \mathrm{~g})$, beef infusion $(30 \mathrm{~g})$, casein hydrolysate $(1.75 \mathrm{~g})$, agar $(1.7 \mathrm{~g})$, and distilled water $(1000 \mathrm{~mL})$; its $\mathrm{pH}$ was adjusted to neutral at $37 \pm 2^{\circ} \mathrm{C}$. Different concentrations of 500 and $1000 \mathrm{ppm}$ were made by dissolving the compounds in DMSO and soaked in Whatman no. 1 filter paper discs of 5-millimeter diameter. The bacterial suspensions were matched to $0.5 \mathrm{McF}$ arland turbidity standard. The dried discs were placed on the antecedently seeded petri plates and incubated at $37^{\circ} \mathrm{C}$ for $24 \mathrm{~h}$. The diameter of the inhibition zone around every disc was measured exactly in millimeter and compared therewith of the standard antibiotic (Streptomycin), whose antibacterial activity was conjointly determined by a similar technique. The susceptibility assessments were performed on the basis of the diameter of the zone of inhibition against various strains of bacteria.

\section{In-Vitro Antifungal Activity}

The antifungal activity of the ligands $\left(\mathrm{HL}^{1}\right.$ and $\left.\mathrm{HL}^{2}\right)$ and complexes were checked in-vitro againstCandida albicans (ATCC 200360) and Aspergillus flavus (ATCC 204304) by the Kirby-Bauer well diffusion technique [Itraconazole was used as a positive control for antifungal activity]. Each culture to be screened was marked on to a non-inhibitory agar medium to induce isolated colonies. Once incubated at $35^{\circ} \mathrm{C}$ overnight, 4 or 5 well-isolated colonies were chosen with an inoculum's needle and 
RASĀYAN J. Chem.

Vol. 12 | No. 4 |2328 - 2337| October - December | 2019

were moved to a tube of sterile saline broth. The yeasts were used to prepare the inoculum from a $24 \mathrm{~h}$ culture on Sabouraud dextrose agar. Petri dishes ( $8 \mathrm{~cm}$ diameter) containing $20 \mathrm{~cm}^{3}$ of Sabouraud dextrose agar, as a solid media for preparing wells were used for analysis. The study compound was introduced in the well $(6 \mathrm{~mm})$ after diluting the indefinite quantity of dimethylsulphoxide (DMSO) so as to obtain concentrations of 50 and 100ppm for antibacterial activity and 50, 100 and $200 \mathrm{ppm}$ for antifungal activity. These Petri plates were incubated at $35^{\circ} \mathrm{C}$ for $24-48 \mathrm{~h}$. The controls were conjointly run and 3 replicates were employed in every case. When incubation, the diameter of the zones of complete inhibition (including the diameter of the well) was measured and recorded. To obtain the linear growth of the fungus the diameter of the fungal colony was measured after four days and the percentage inhibition was calculated as;

$$
\text { Inhibition }=\frac{C-T}{C} X 100 \%
$$

Where $\mathrm{C}$ and $\mathrm{T}$ are the diameters of the fungal colony in control and test plates, respectively, after $96 \mathrm{~h}$. The antifungal activity of the compounds was compared with that of the standard compound.

\section{In Vitro Antimycobacterial Activity}

The antimycobacterial activity of the ligands and their $\mathrm{Co}$ (II) and $\mathrm{Ni}$ (II) complexes against Mycobacterium tuberculosis bacteria - strain - H37RV - sensitive to isoniazid and rifampicin drugs was evaluated(Fig.-3). For antimycobacterial susceptibility testing ${ }^{26}$ of different compounds against Mycobacterium tuberculosis MGIT ${ }^{\mathrm{TM}}$ DST method was used. For better recovery and faster growth of Mycobacteria Growth Indicator Tube consisting of liquid broth medium was used. The MGIT contains $7.0 \mathrm{~mL}$ of modified Middle brook $7 \mathrm{H} 9$ broth base. Autoclaving was used to sterilize the medium. To make the medium complete addition of an enrichment3 MGIT OADC (Oleic acid, Albumin, Dextrose and Catalase) or MGIT 960 Growth Supplement. This Growth Supplement is essential for the growth of many mycobacteria, especially those belonging to Mycobacterium tuberculosis complex. The MGIT PANTA is added to necessarily suppress contamination. Given compounds were diluted according to the required concentrations $(100 \mathrm{mg} / \mathrm{mL})$. A total 9 MGIT tubes were labeled and $0.8 \mathrm{~mL}$ supplement was added to each tube. The $1^{\text {st }}$ tube was then kept aside and compounds $100 \mu \mathrm{L}$ from the stock of $100 \mathrm{mg} / \mathrm{mL}$ were added to the respective tubes. $2^{\text {nd }}$ to $9^{\text {th }}$ tubes were mixed properly and kept aside. 1:100 dilution of DST inoculum (M. tuberculosis (H37RV) was prepared for the growth control tube ( $1^{\text {st }}$ tube) and 1:5 dilution of DST inoculum (M. tuberculosis H37RV was prepared for tubes $2^{\text {nd }}$ to $5^{\text {th }} .0 .5 \mathrm{~mL}$ of $1: 100$ dilutions were added to the $1^{\text {st }}$ tube (Growth control tube). $0.5 \mathrm{~mL}$ of $1: 5$ dilution was added to tubes $2^{\text {nd }}$ to $9^{\text {th }}$.All tubes were incubated in MGIT-320 instruments at $37^{\circ} \mathrm{C}$ and observed for the growth of the bacterium.

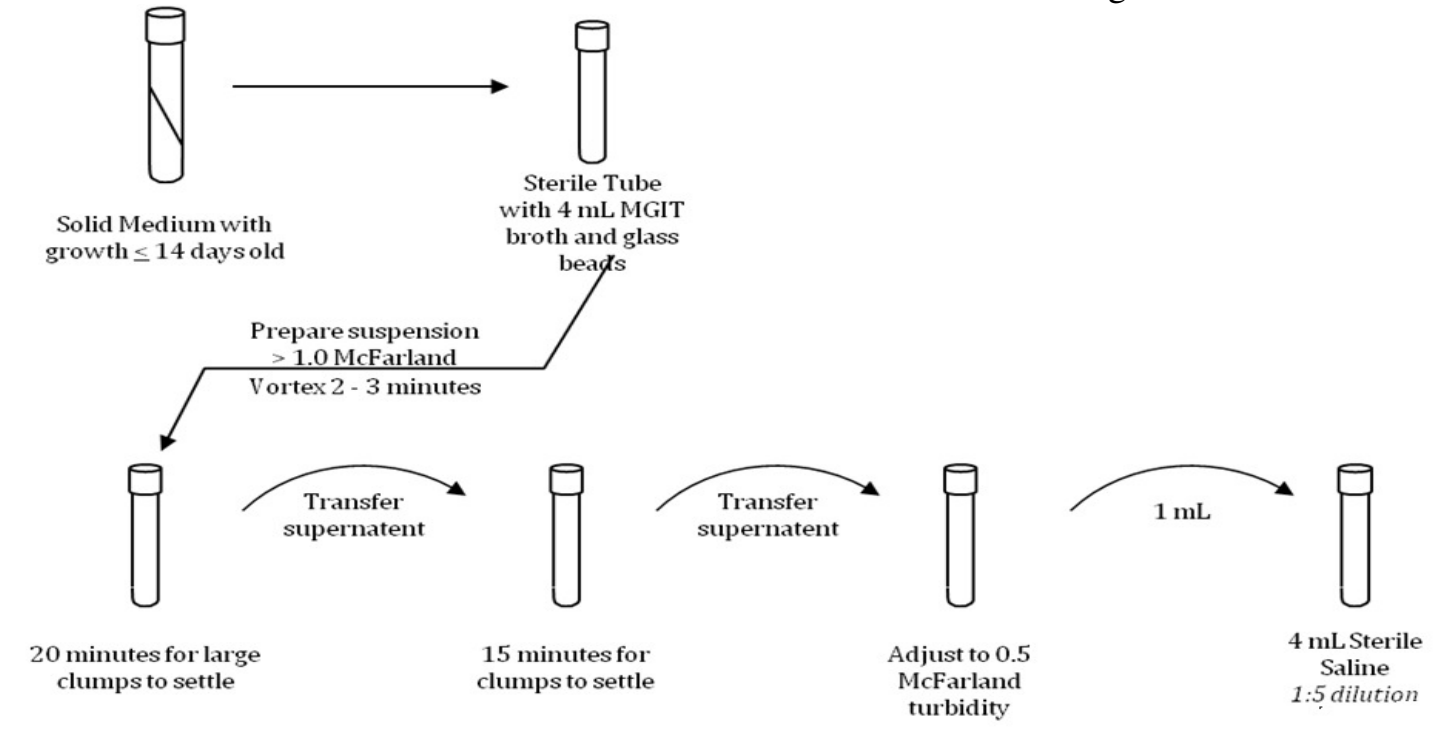

Fig.-3: MGITTM DST Preparation \&Inoculation (From solid media) 
RASĀYAN J. Chem.

Vol. 12 | No. 4 |2328 - 2337| October - December | 2019

\section{RESULTS AND DISCUSSION}

The obtained Schiff base metal complexes were colored powders. The elemental and spectral analyses revealed ligands $\left(\mathrm{HL}^{1}\right.$ and $\left.\mathrm{HL}^{2}\right)$ and their metal complexes of the type $\mathrm{Co}\left(\mathrm{L}^{1}\right)(\mathrm{OAc}) \cdot 3 \mathrm{H}_{2} \mathrm{O}$, $\mathrm{Co}\left(\mathrm{L}^{1}\right)_{2} \cdot 2 \mathrm{H}_{2} \mathrm{O}, \quad \mathrm{Ni}\left(\mathrm{L}^{1}\right)(\mathrm{OAc}) \cdot 3 \mathrm{H}_{2} \mathrm{O}, \quad \mathrm{Ni}\left(\mathrm{L}^{1}\right)_{2} \cdot 2 \mathrm{H}_{2} \mathrm{O}, \quad \mathrm{Co}\left(\mathrm{L}^{2}\right)(\mathrm{OAc}) \cdot 3 \mathrm{H}_{2} \mathrm{O}, \quad \mathrm{Co}^{2}\left(\mathrm{~L}^{2}\right)_{2} \cdot 2 \mathrm{H}_{2} \mathrm{O}$, $\mathrm{Ni}\left(\mathrm{L}^{2}\right)(\mathrm{OAc}) \cdot 3 \mathrm{H}_{2} \mathrm{O}$, and $\mathrm{Ni}\left(\mathrm{L}^{2}\right)_{2} \cdot 2 \mathrm{H}_{2} \mathrm{O}$ (Fig. 4). The metal complexes were prepared by mixing a boiling ethanolic solution of $\mathrm{HL}^{1}$ and $\mathrm{HL}^{2}$ with an aqueous ethanolic solution of $\mathrm{Co}$ (II) and $\mathrm{Ni}$ (II) acetates to cause instant precipitation of metal complexes. The solid products were filtered off and removal of unreacted metal acetates or ligands was done by washing them with warm water and aqueous ethanol.

\section{Spectroscopic Characterization \\ IR Spectra}

In Table-2 significant IR bands of the Schiff base ligands and their metal complexes are reported. The $v(\mathrm{C}=\mathrm{N})$ stretch of the free azomethine in the region $1595-1615 \mathrm{~cm}^{-1}$ is shifted to a lower frequency (as a result of chelation) by $15-20 \mathrm{~cm}^{-1}$ owing to the coordination of azomethine nitrogen to the metal ion. The two sharp bands around $3450 \mathrm{~cm}^{-1}$ (asymmetric vibrations) and $3350 \mathrm{~cm}^{-1}$ (symmetric vibrations) of the $\mathrm{NH}_{2}$ group in the ligands remain unaltered in the spectra of the metal complexes suggesting nonparticipation of $-\mathrm{NH}_{2}$ group in the chelation. Due to keto-enol tautomerism and subsequent coordination of the complexes through the enolic oxygen/thiolic sulfur atom $v(\mathrm{C}=\mathrm{O})$ band in hydrazinecarboxamide and $v(C=S)$ in hydrazinecarbothioamide appear at $1690 \mathrm{~cm}^{-1}$ and $1035 \mathrm{~cm}^{-1}$ are shifted towards lower frequency.

The spectra of the metal complexes show broad bands in the range of $3340-3525 \mathrm{~cm}^{-1}$ indicating the presence of coordinated water molecules. Bands in the range $1540-1555 \mathrm{~cm}^{-1}$ and $1365-1370 \mathrm{~cm}^{-1}$ correspond to the symmetric and asymmetric vibrations of the acetate groups which suggests the coordination of the acetate group to the metal ion through one oxygen atom (here the acetate group acts as a monodentate ligand). Intense band within $1720-1728 \mathrm{~cm}^{-1}$ is assigned to the $v(\mathrm{OCOCH} 3)$ vibration in the 1: 1 metal complexes. The bands in the far IR spectra of all the metal complexes were in the range of $470-430 \mathrm{~cm}^{-1}, 330-350 \mathrm{~cm}^{-1}$ and $510-525 \mathrm{~cm}^{-1}$ were assigned to $v(\mathrm{M}-\mathrm{N}), v(\mathrm{M}-\mathrm{S})$ and $v(\mathrm{M}-\mathrm{O})$ vibrations, respectively.

Table-2: IR Vibrational Frequencies $\left(\mathrm{Cm}^{-1}\right)$ For the Ligands and Their Corresponding Complexes

\begin{tabular}{c|c|c|c|c|c|c}
\hline Compound & $v(\mathrm{NH})$ & $v(\mathrm{C}=\mathrm{N})$ & $v\left(\mathrm{OCOCH}_{3}\right)$ & $v(\mathrm{M}-\mathrm{O})$ & $v(\mathrm{M}-\mathrm{S})$ & $v\left(\mathrm{H}_{2} \mathrm{O} / \mathrm{OH}\right)$ \\
\hline $\mathrm{HL}^{1}$ & 3260 & 1610 & - & - & - & - \\
\hline $\mathrm{HL}^{2}$ & 3264 & 1615 & - & - & - & - \\
\hline $\mathrm{Co}\left(\mathrm{L}^{1}\right)(\mathrm{OAc}) \cdot 3 \mathrm{H}_{2} \mathrm{O}$ & - & 1593 & 1727 & 514 & - & 3354 \\
\hline $\mathrm{Co}\left(\mathrm{L}^{1}\right) 2 \cdot 2 \mathrm{H}_{2} \mathrm{O}$ & - & 1592 & - & 519 & - & 3352 \\
\hline $\mathrm{Ni}\left(\mathrm{L}^{1}\right)(\mathrm{OAc}) \cdot 3 \mathrm{H}_{2} \mathrm{O}$ & - & 1595 & 1722 & 528 & - & 3346 \\
\hline $\mathrm{Ni}\left(\mathrm{L}^{1}\right) 2 \cdot 2 \mathrm{H}_{2} \mathrm{O}$ & - & 1598 & - & 532 & - & 3302 \\
\hline $\mathrm{Co}\left(\mathrm{L}^{2}\right)(\mathrm{OAc}) \cdot 3 \mathrm{H}_{2} \mathrm{O}$ & - & 1596 & 1724 & - & 353 & 3350 \\
\hline $\mathrm{Co}\left(\mathrm{L}^{2}\right) 2 \cdot 2 \mathrm{H}_{2} \mathrm{O}$ & - & 1592 & - & - & 350 & 3354 \\
\hline $\mathrm{Ni}\left(\mathrm{L}^{2}\right)(\mathrm{OAc}) \cdot 3 \mathrm{H}_{2} \mathrm{O}$ & - & 1597 & 1726 & - & 347 & 3348 \\
\hline $\mathrm{Ni}\left(\mathrm{L}^{2}\right) 2 \cdot 2 \mathrm{H}_{2} \mathrm{O}$ & - & 1594 & - & - & 349 & 3300 \\
\hline
\end{tabular}

\section{${ }^{1} \mathrm{H}$ NMR Spectra}

DMSO- $\mathrm{d}_{6}$ solution was used to record the ${ }^{1} \mathrm{H}$ NMR spectra of the ligands (Table- 3 ). The ligands $\mathrm{HL}^{1}$ and $\mathrm{HL}^{2}$ exhibit $-\mathrm{NH}$ proton resonance signals at $\delta 10.23$ and $10.28 \mathrm{ppm}$, respectively. A singlet at 8.33 and $8.34 \mathrm{ppm}$ in ligands is due to $-\mathrm{CH}=\mathrm{N}$ protons. The signals observed at 2.16 and $2.18 \mathrm{ppm}$ are due to $-\mathrm{NH}_{2}$ group in the spectra of $\mathrm{HL}^{1}$ and $\mathrm{HL}^{2}$, respectively. The spectrum of the ligand exhibited signals at 6.70 $7.72 \mathrm{ppm}$ due to aromatic protons.

Table-3: Chemical Shift $\left(\delta\right.$, ppm) in ${ }^{1} \mathrm{H}$ NMR Spectra of the Ligands

\begin{tabular}{c|c|c|c|c}
\hline Compounds & $-\mathrm{NH}$ & $-\mathrm{NH} 2$ & $-\mathrm{CH}=\mathrm{N}$ & Aromatic \\
\hline $\mathrm{HL}^{1}$ & 10.23 & 2.16 & 8.33 & $6.72-7.78$ \\
\hline $\mathrm{HL}^{2}$ & 10.28 & 2.18 & 8.34 & $6.73-7.80$ \\
\hline
\end{tabular}




\section{Electron Absorption Spectra}

The electron absorption spectra were used to determine the stereochemistry of metal ions in the complexes. The electronic spectra of thecobalt(II) complexes are characterized by three transitions; $4 T_{1 g}(\mathrm{~F}) \rightarrow 4 T_{2 g}(\mathrm{P})\left(v_{1}\right), 4 T_{1 g}(\mathrm{~F}) \rightarrow 4 A_{2 g}(\mathrm{~F})\left(v_{2}\right)$, and $4 T_{1 g}(\mathrm{~F}) \rightarrow 4 T_{1 g}(\mathrm{P})\left(v_{3}\right)$. The spectra of the $\operatorname{Co}(\mathrm{II})$ complexes contain three absorption bands in the regions 9260-9490, 19425-20420, 21490-22001 cm which clearly indicate the octahedral stereochemistry of the complexes. The following equation was used to calculate the ligand field parameters $(D q, B, \beta$, and $\beta \%)$ for the Co(II) complexes -

$$
\begin{gathered}
\mathrm{Dq}=v_{2}-v_{1} / 10 \\
\mathrm{~B}=v_{2}+v_{3}-3 v_{1} / 15
\end{gathered}
$$

The Racah parameter $(B)$ is found to be $870-935 \mathrm{~cm}^{-1}\left(<971 \mathrm{~cm}^{-1}\right)$ suggesting an orbital overlap and delocalization of the electron on the metal ion. The partial covalent character for the 1: 1 and 1: 2 cobalt complexes is indicated by nephelauxetic ratio $(\beta)$ which is less than one. The values for Dq, $\mathrm{B}, \beta \%, v_{2} / v_{1}$ are listed in Table 4.

Three absorption bands in the regions of $9800-9950 \mathrm{~cm}^{-1}, 16200-16600 \mathrm{~cm}^{-1}$, and $24800-25000 \mathrm{~cm}^{-1}$ for $\mathrm{Ni}(\mathrm{II})$ complexes have been assigned to $3 \mathrm{~A}_{2 \mathrm{~g}}(\mathrm{~F}) \rightarrow 3 \mathrm{~T}_{2 \mathrm{~g}}(\mathrm{~F})\left(v_{1}\right), 3 \mathrm{~A}_{2 \mathrm{~g}}(\mathrm{~F}) \rightarrow 3 \mathrm{~T}_{1 \mathrm{~g}}(\mathrm{~F})\left(v_{2}\right)$ and $3 \mathrm{~A}_{2 \mathrm{~g}}(\mathrm{~F})$ $\rightarrow 3 \mathrm{~T}_{1 \mathrm{~g}}(\mathrm{P})\left(v_{3}\right)$ transitions, respectively. These transitions clearly indicate octahedral geometry for the $\mathrm{Ni}$ (II) ion. By using the Band-fitting equation ${ }^{27}$, ligand field parameters ${ }^{28}$ have been determined for these complexes.

$$
\begin{gathered}
\mathrm{Dq}=v_{1} / 10 \\
\mathrm{~B}=v_{2}+v_{3}-3 v_{1} / 15
\end{gathered}
$$

The presence of a covalent character in the metal-ligand bond has been ascertained by the value of Racah parameter B which is less than the free ion value i.e. $1041 \mathrm{~cm}^{-1}$. Based on analytical and spectral data the following octahedral structures have been proposed (Fig.-4).

\section{Thermal Analysis}

Thermal analyses were performed in an atmosphere at a heating rate of $10^{\circ} \mathrm{C} / \mathrm{min}$ up to $900^{\circ} \mathrm{C}$ and are shown in Fig.5. The decomposition model observed is almost similar for all Schiff base metal complexes, therefore only two complexes $\mathrm{Ni}\left(\mathrm{L}_{1}\right) \mathrm{OAc} .3 \mathrm{H}_{2} \mathrm{O}$ and $\mathrm{Co}\left(\mathrm{L}_{1}\right) \mathrm{OAc} .3 \mathrm{H}_{2} \mathrm{O}$ are discussed here in detail. The TG curve tells us about the thermal stability and the product formed on heating. Both compounds show almost the same thermal stability. The results of thermal studies reveal show that the complexes generally decompose in several thermal steps. The first step represents a dehydration step i.e. the elimination of the water molecules. In the second step, elimination of organic moiety takes place and finally, the formation of $\mathrm{CoO}$ and $\mathrm{NiO}$ takes place at $704^{\circ} \mathrm{C}$ for Co complex and $724^{\circ} \mathrm{C}$ for Ni complex, respectively.

\section{Biological Aspect Antimicrobial Assay}

All the Schiff base ligands and their complexes were found to be biologically potent for antimicrobial assay. In distinction to free ligands, Schiff base metal complexes disclosed significantly enriched antimicrobial activity against microorganism strains. Concentration plays a significant role in enhancing the degree of inhibition. Antifungal and bacterial activities increase with increasing concentration. In terms of Overtone's idea and Tweedy's chelation theory ${ }^{29}$ the enhanced activity of the synthesized Schiff base metal complexes than the ligands might even be explained. Consistent with Overtone's conception and Tweety's chelation theory, the liposolubility is a very important factor that limits antimicrobial activity. A lipid semipermeable membrane favors the passage of materials that dissolve in lipids. As the chelation increases, the polarity of the metal ion reduces owing to the overlapping of the ligand orbitals and a partial sharing of the electric charge of the metal ion with the charge of the donor group i.e. ligand. In other words we are able to say that the lipophilicity of cell membranes is augmented because of Schiff base metal complexes. This reduces the whole-cell electron density on the free ligand that elicited an electron delocalization over the entire chelate ring. As delocalization of electrons is larger over the whole chelate ring, the lipophilicity of the complexes is augmented. This favors permeation through the lipid layer of the semipermeable membrane and thus the complexes can simply penetrate into a lipid membrane and block the metal-binding sites in enzymes of microorganisms. These complexes collectively interrupt the regular cellular method and thus block further growth of the organism that deactivates the metabolic 
RASĀYAN J. Chem.

Vol. 12 | No. 4 |2328 - 2337| October - December | 2019

pathways of those microorganisms. In general, metal complexes are more active than the ligands as they may serve as principal cytotoxic species. Thus, the complexes as an antimicrobial agent can realize more applications in the pharmaceutical industry ${ }^{30,31}$ once testing their toxicity. The antimicrobial activity of the ligands and their $\mathrm{Co}$ (II) and $\mathrm{Ni}$ (II) complexes against morbific bacteria and fungi is conferred in Figs.-6 and 7 severally.
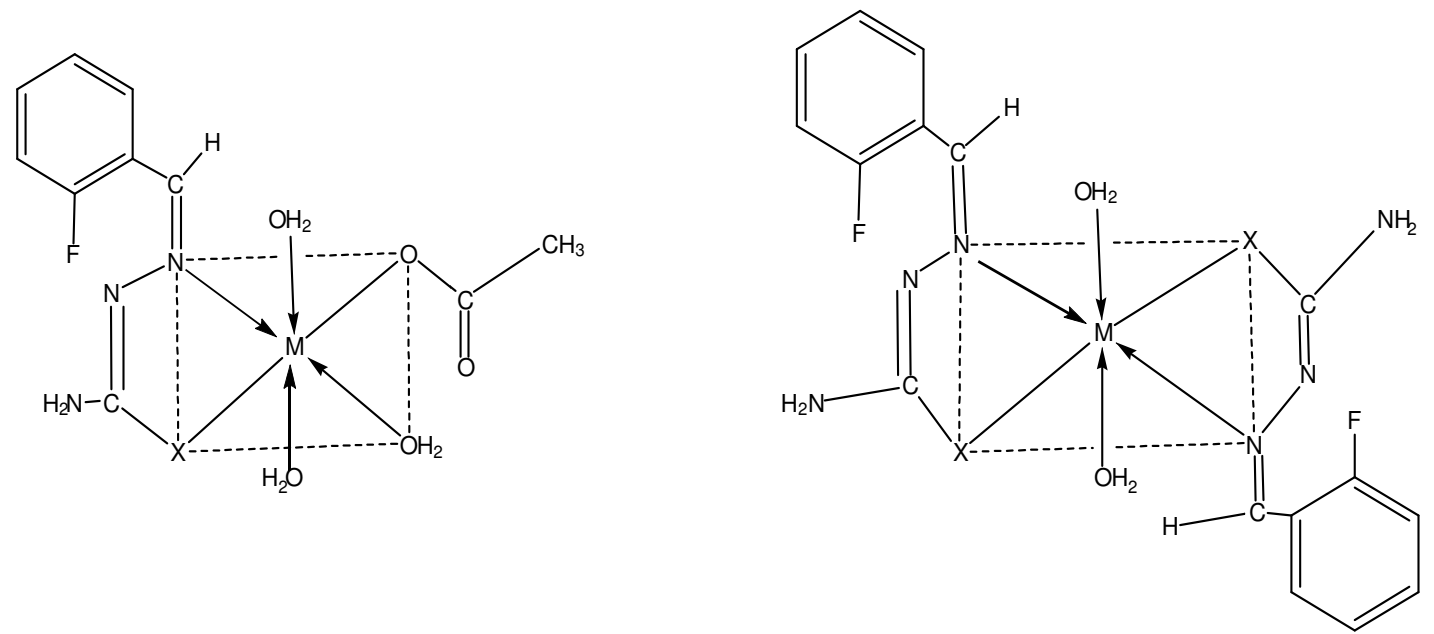

Fig.-4: Proposed Structure Of Complexes (A) 1:1 (B) 1:2; where $\mathrm{M}=\mathrm{Co}$ and Ni

Table-4: Electron Transition Frequencies and Ligand Field Parameters of The Metal Complexes

\begin{tabular}{|c|c|c|c|c|c|c|c|c|}
\hline \multirow[t]{2}{*}{ Compound } & \multicolumn{3}{|c|}{ Frequency, $\mathrm{cm}^{-1}$} & \multirow{2}{*}{$\begin{array}{l}\mathrm{Dq}, \\
\mathrm{cm}^{-1}\end{array}$} & \multirow{2}{*}{$\begin{array}{c}\mathrm{B} \\
\mathrm{cm}^{-1}\end{array}$} & \multirow[t]{2}{*}{$v_{2} / v_{1}$} & \multirow[t]{2}{*}{$\mathrm{B}$} & \multirow[t]{2}{*}{$\beta \%$} \\
\hline & $v_{1}$ & $v_{2}$ & $v_{3}$ & & & & & \\
\hline $\mathrm{Co}\left(\mathrm{L}^{1}\right)(\mathrm{OAc}) \cdot 3 \mathrm{H}_{2} \mathrm{O}$ & 9276 & 19433 & 21493 & 1015.7 & 873.2 & 2.09 & 0.899 & 10.1 \\
\hline $\mathrm{Co}\left(\mathrm{L}^{1}\right) 2 \cdot 2 \mathrm{H}_{2} \mathrm{O}$ & 9339 & 19606 & 21530 & 1026.7 & 874.6 & 2.09 & 0.900 & 10.0 \\
\hline $\mathrm{Ni}\left(\mathrm{L}^{1}\right)(\mathrm{OAc}) \cdot 3 \mathrm{H}_{2} \mathrm{O}$ & 9931 & 15380 & 22740 & 993.1 & 544.9 & 1.54 & 0.523 & 47.7 \\
\hline $\mathrm{Ni}\left(\mathrm{L}^{1}\right) 2 \cdot 2 \mathrm{H}_{2} \mathrm{O}$ & 9982 & 15471 & 22819 & 998.2 & 556.2 & 1.54 & 0.534 & 46.6 \\
\hline $\mathrm{Co}\left(\mathrm{L}^{2}\right)(\mathrm{OAc}) \cdot 3 \mathrm{H}_{2} \mathrm{O}$ & 9485 & 19902 & 21822 & 1041.7 & 884.6 & 2.09 & 0.911 & 8.90 \\
\hline $\mathrm{Co}\left(\mathrm{L}^{2}\right) 2 \cdot 2 \mathrm{H}_{2} \mathrm{O}$ & 9470 & 20413 & 21997 & 1094.3 & 933.3 & 2.15 & 0.961 & 3.90 \\
\hline $\mathrm{Ni}\left(\mathrm{L}^{2}\right)(\mathrm{OAc}) \cdot 3 \mathrm{H}_{2} \mathrm{O}$ & 9926 & 15090 & 24849 & 992.6 & 677.4 & 1.52 & 0.650 & 35.0 \\
\hline $\mathrm{Ni}\left(\mathrm{L}^{2}\right) 2 \cdot 2 \mathrm{H}_{2} \mathrm{O}$ & 9952 & 15310 & 24855 & 995.2 & 687.2 & 1.53 & 0.660 & 3.00 \\
\hline
\end{tabular}

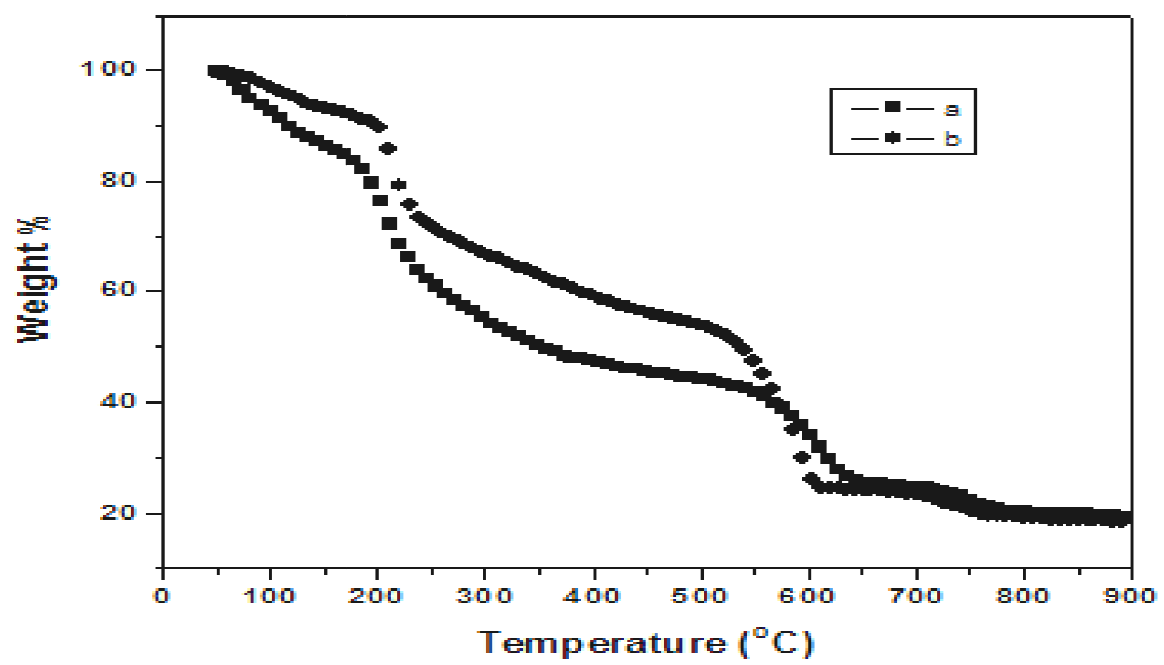

Fig.-5: Thermo Gravimetric Curves for (a) $\mathrm{CO}\left(\mathrm{L}^{1}\right) \mathrm{OAc} .3 \mathrm{H}_{2} \mathrm{O}$; (b) $\mathrm{Ni}\left(\mathrm{L}^{1}\right) \mathrm{OAc} .3 \mathrm{H}_{2} \mathrm{O}$ Metal Complexes 


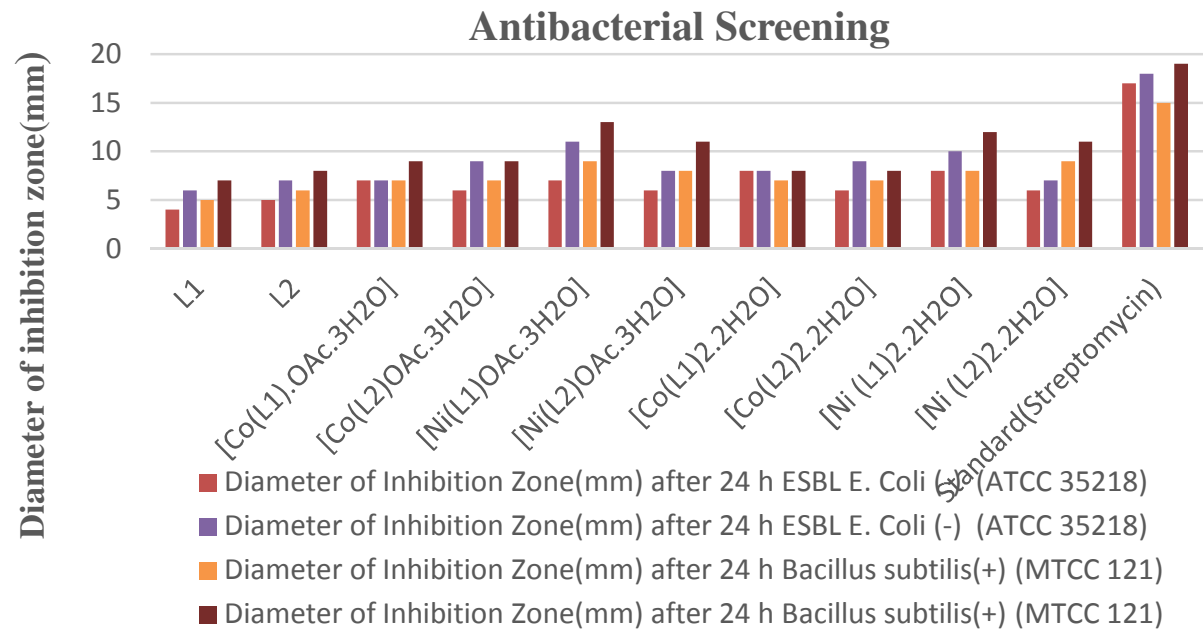

Fig.-6: Data on the Antibacterial Screening of the Ligands and Their Co(II) and Ni(II) Complexes

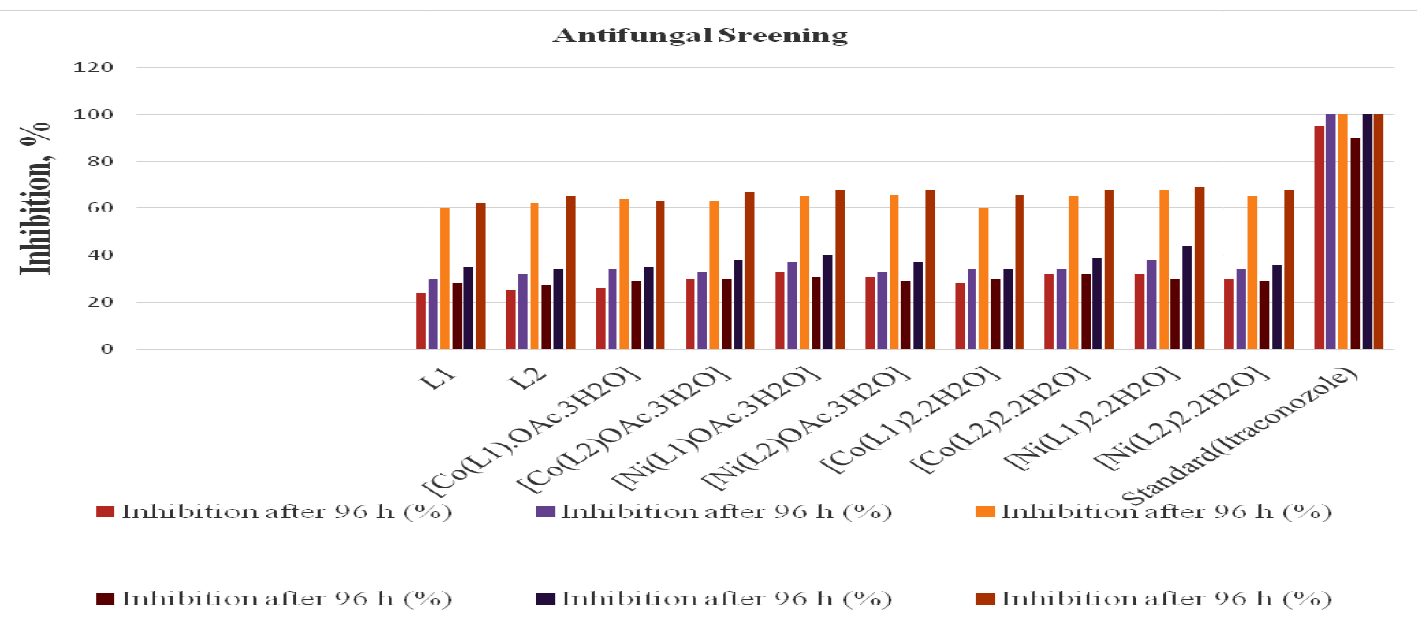

Fig. -7: Data on the Antifungal Screening of the Ligands and their Co(II) and Ni(II) Complexes after $96 \mathrm{H}$ of Inhibition (\%)

\section{Antimycobacterial Activity}

Results of antimycobacterial activity are shown in Table-5. Only one of the compounds $\mathrm{Co}\left(\mathrm{L}^{2}\right) 2 \cdot 2 \mathrm{H}_{2} \mathrm{O}$ arrested the growth of Mycobacterium tuberculosis bacteria-Strain-H37RV.

Table-5:Antimycobacterial Activity of Synthesized Compounds Against Mycobacterium Tuberculosis Bacteria Strain - H37RV - Sensitive To Isoniazid And Rifampicin Drugs

\begin{tabular}{c|c|c|c}
\hline Tube Number & $\begin{array}{c}\text { Compound Number } \\
\text { Coding }\end{array}$ & Concentration used per vial & $\begin{array}{c}\text { Growth Observed } \\
\text { M. tuberculosis }(\mathrm{H} 37 \mathrm{Rv})\end{array}$ \\
\hline 1 & Growth Control & Nil & Yes \\
\hline 2 & $\mathrm{Co}\left(\mathrm{L}^{1}\right)(\mathrm{OAc}) \cdot 3 \mathrm{H}_{2} \mathrm{O}$ & $100 \mathrm{ul}$ (volume) from the stock of $100 \mathrm{mg} / \mathrm{ml}$ & Yes \\
\hline 3 & $\mathrm{Co}\left(\mathrm{L}^{1}\right) 2 \cdot 2 \mathrm{H}_{2} \mathrm{O}$ & $100 \mathrm{ul}$ (volume) from the stock of $100 \mathrm{mg} / \mathrm{ml}$ & Yes \\
\hline 4 & $\mathrm{Ni}\left(\mathrm{L}^{1}\right)(\mathrm{OAc}) \cdot 3 \mathrm{H}_{2} \mathrm{O}$ & $100 \mathrm{ul}$ (volume) from the stock of $100 \mathrm{mg} / \mathrm{ml}$ & Yes \\
\hline 5 & $\mathrm{Ni}\left(\mathrm{L}^{1}\right) 2 \cdot 2 \mathrm{H}_{2} \mathrm{O}$ & $100 \mathrm{ul}$ (volume) from the stock of $100 \mathrm{mg} / \mathrm{ml}$ & Yes \\
\hline 6 & $\mathrm{Co}\left(\mathrm{L}^{2}\right)(\mathrm{OAc}) \cdot 3 \mathrm{H}_{2} \mathrm{O}$ & $100 \mathrm{ul}$ (volume) from the stock of $100 \mathrm{mg} / \mathrm{ml}$ & Yes \\
\hline 7 & $\mathrm{Co}\left(\mathrm{L}^{2}\right) 2 \cdot 2 \mathrm{H}_{2} \mathrm{O}$ & $100 \mathrm{ul}($ volume) from the stock of $100 \mathrm{mg} / \mathrm{ml}$ & No \\
\hline 8 & $\mathrm{Ni}\left(\mathrm{L}^{2}\right)(\mathrm{OAc}) \cdot 3 \mathrm{H}_{2} \mathrm{O}$ & $100 \mathrm{ul}($ volume) from the stock of $100 \mathrm{mg} / \mathrm{ml}$ & Yes \\
\hline 9 & $\mathrm{Ni}\left(\mathrm{L}^{2}\right) 2 \cdot 2 \mathrm{H}_{2} \mathrm{O}$ & $100 \mathrm{ul}($ volume) from the stock of $100 \mathrm{mg} / \mathrm{ml}$ & Yes \\
\hline
\end{tabular}


RASĀYAN J. Chem.

Vol. 12 | No. 4 | 2328 - 2337| October - December | 2019

\section{CONCLUSION}

The present paper reports preparation and spectroscopic characterization of new mononuclear complexes of $\mathrm{Co}(\mathrm{II})$ and $\mathrm{Ni}$ (II) with nitrogen and oxygen/Sulfur donor Schiff base ligands. The coordination behavior of ligand to the metal ion is confirmed by spectral studies like UV-Visible, IR, NMR and TGA. From the analytical and spectral data, both cobalt(II) and nickel(II) complexes were shown to exhibit an octahedral geometry. The ligand field parameters ( $\mathrm{Dq}, \mathrm{B}, \beta$, and $\beta \%)$ indicate that the metal-ligand bonds have a significant covalent character. Antimicrobial studies of the ligands and complexes were performed which indicates that the activity increases on chelation. Among the synthesized $\mathrm{Co}$ (II) and $\mathrm{Ni}$ (II) coordination compounds, $\left[\mathrm{Co}\left(\mathrm{L}^{2}\right)_{2} 2 \mathrm{H}_{2} \mathrm{O}\right]$ of thiosemicarbazonehas shown relatively promising results against Mycobacterium tuberculosis. It may find application as an antimycobacterial agent after further study of its biological properties.

\section{ACKNOWLEDGMENT}

The authors are thankful to the University Grants Commission and Council of Scientific and Industrial Research (India) for financial support and to Dr. B. Lal lab for the biological study.

\section{REFERENCES}

1. K.C. Gupta and A.K. Sutar, Coordination Chemistry Review, 252, 1420(2008), DOI: $10.1016 /$ j.ccr.2007.09.005

2. T. Jinkhoo, M. K. binBreakm, K.A. Crouse, M.I.M. Tahir, A. M. Ali, A.R. Cowley,D.J. Watkin, M. T. H. Tarafder, Inorganica Chimica Acta, 413, 68(2014), DOI:10.1016/j.ica.2014.01.001

3. N. Fahmi, R. Meena, P. Mitharwal, S. Shrivastava, and R.V. Singh, International Journal of Pharmaceutical Sciences and Research, 5(7), 2821(2014), DOI:10.13040/IJPSR.09758232.5(7).2821-33.

4. A.D. Kulkarni, S.A. Patil, V.H. Naik, and P.S. Badami, Spectrochimica. Acta Part A, 75, 347(2009), DOI:10.1016/j.saa.2009.10.039.

5. G.G. Iopedre, M.I.F. Garca, A.M.G. Noya, M.A.V. Fernandez, M.R. Bermejo, and M. Maneiro, Physical Chemistry Chemical Physics, 13, 18069(2011), DOI:10.1039/C1CP21154D.

6. Malik, S., Ghosh. S., and B. Jain., J. Ind. Council Chem., 27(2), 173(2010).

7. Mustapha, A., Duckmanton P., Reglinski J., and Kennedy A. R., Polyhedron, 29, 2590(2010), DOI: $10.1016 /$ j.poly.2010.06.001.

8. S. A. Matara, W.H. Talibb, M.S. Mustafac, M.S. Mubarak, M. A. AlDamenc,Arabian Journal of Chemistry, 8(6), 850(2015), DOI:10.1016/j.arabjc.2012.12.039

9. P. Kapoor, R.V. Singh, and N. Fahmi, Journalof Coordination Chemistry, 65(2), 262(2012), DOI: $10.1080 / 00958972.2011 .649265$

10. L. Dawara, and R.V. Singh, Applied Organometallic Chemistry, 25, 643(2011), DOI: 10.1002/aoc. 1813

11. S.A. Khan, A. M. Asiri, K. Al-Amry, and M.A Malik, The Scientific World Journal, 592375(2014), DOI: $10.1155 / 2014 / 592375$

12. X. Zhang, C.B. Sangani, L.X. Jia, P.X. Gong, F. Wang, J.F. Wang and H. L. Zhu, RSC Advances, 4, 54217(2014), DOI: 10.1039/C4RA08567A

13. P. Nirmala Jyothi and B. Sireesha, Rasayan Journal of Chemistry, 12(3), 1530(2019), DOI: $10.31788 / R J C .2019 .1235182$

14. A. Carreño, C. Zúñiga, D. P. Hernández, M. Gacitúa, R. Polanco, C. Otero, R. A. Pérez and J.A. Fuentes, New Journal Chemistry,42, 8851(2018) , DOI:10.1039/C8NJ00390D

15. G. B. Bagihalli, P.G. Avaji, S.A. Patil, and P.S. Badami, European Journal of Medicinal Chemistry, 42, 2639(2008), DOI:10.1016/j.ejmech.2008.02.013

16. E. Pahontu, F. Julea, T. Rosu, and V. Purcarea,Journal of Cellular and Molecular Medicine, 19, 865(2015), DOI: $10.1111 / \mathrm{jcmm} .12508$.

17. P.B. Babasaheb, S.G. Shrikant, G.B. Ragini, V.T. Jalinder and N.K. Chandrahas, Bioorganic \& Medicinal Chemistry, 18, 1364(2010), DOI:10.1016/j.bmc.2009.11.066

18. S. Kashanian, M.M. Khodaei, H. Roshanfekr, N. Shahabadi, A. and Mansouri G., Spectrochim Acta A Mol. Bimol. Spectrosc., 86, 351(2011), DOI: 10.1016/j.saa.2011.10.048 
19. M. Kratky, M. Dzurkova, J.R. Janousek, K.K. Cna, F. Trejtnar, J.R.S. Rikova, and J. Vinsova, Molecules, 22, 1573(2017), DOI:10.3390/molecules22091573

20. K.S. Prasad, L.S. Kumar, M. Prasad, Jayalakshmi and H.D. Revanasiddappa, Spectrochimica ActaA, 81, 276-282-138(2011), DOI: 10.1016/j.saa.2011.06.010

21. K. Sampath, R. Ashokkumar, A. Venkatachalam and M. Shanmugaprakash, Rasayan Journal of Chemistry, 12(1), 257(2019), DOI: 10.31788/RJC.2019.1214099

22. D. Mandal and Bikramaditya Mandal, Rasayan Journal of Chemistry, 12(2), 754(2019), DOI: 10.31788/RJC.2019.1225230

23. A. Kaul, E. Aremoult, N. Lounis, J. Guillemont, and K. Andries, Nature, 469, 483 (2011), DOI: 10.1038/nature09657

24. A. I. Vogel, A Textbook of Quantitative Chemical Analysis, Pearson Education Ltd. U.K., p. 387, $6^{\text {th }}$ ed., (2006).

25. J.T. Makode, and A.S. Aswar. Indian Journal of Chemistry, 43A, 2120(2004).

26. L.B. Reller, M.P. Weinstein and G.L. Woods, Clinical Infectious Diseases, 31 (5), 1209(2000).

27. K. Singh, Y. Kumar, P. Puri, C. Sharma, and K.R. Aneja, Medicinal Chemistry Research, 187,1498(2012), DOI:10.1080/10426507.2012.692128.

28. F.A. Cotton, G. Wilkinson, C.A. Murillo and M. Bochmann, Advanced Inorganic Chemistry, John Wiley, New York, 6th ed., (1999).

29. A. A. Al-Amiery, A.A.H. Kadhum, and A.B. Mohamad, Bioinorganic Chemistry and Applications, 12, Article ID 795812, 6 pages , DOI:10.1155/2012/795812

30. M.Z. Wang, Z.X. Meng,B.L. Liu, G.L. Cai,C.L. Zhang,Inorganic Chemistry Communications, 8(4), 368(2005), DOI:10.1016/j.inoche.2005.01.023

31. S. Padhye, H. Yang, A. Jamadar, Q. C. Cui, D. Chavan, K. Dominiak, J. McKinney, S. Banerjee, Q. P. Dou and F. H. Sarkar, Pharmaceutical Research, 26(8), (2009), DOI: 10.1007/s11095-009-99008.

[RJC-5459/2019] 